\title{
CONF-970201--18 ANL/CMT/CP-.90759 \\ EFFECT OF LEAD CONTENT ON PHASE EVOLUTION AND MICROSTRUCTURAL DEVELOPMENT IN Ag-CLAD Bi-2223 COMPOSITE CONDUCTORS*
}

\author{
N.N. Merchant, V.A. Maroni, A.K. Fischer, S.E. Dorris, W. Zhong, \\ and N. Ashcom \\ Argonne National Laboratory \\ Chemical Technology Division \\ 9700 South Cass Avenue \\ Argonne, IL 60439

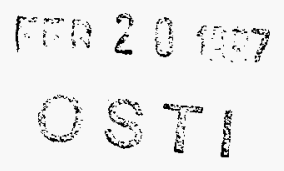

February 1997

Proceedings of a symposium sponsored by the Electronic, Magnetic and Photonic Materials Division (EMPMD) and the Structural Materials Division (SMD) of TMS held during the 1997 TMS Annual Meeting in Orlando, Florida, February 9-13, 1997.

The submitted manuscript has been created by the
University of Chicago as Operator of Argonne
National Laboratory ("Argonne") under Contract No.
W-31-109-ENG-38 with the U.S. Department of
Energy. The U.S. Government retains for itself, and
others acting on its behalf, a paid-up, nonexclusive,
irrevocable worldwide license in said article to
reproduce, prepare derivative works, distribute copies
to the public, and perform publicly and display
publicly, by or on behalf of the Government.
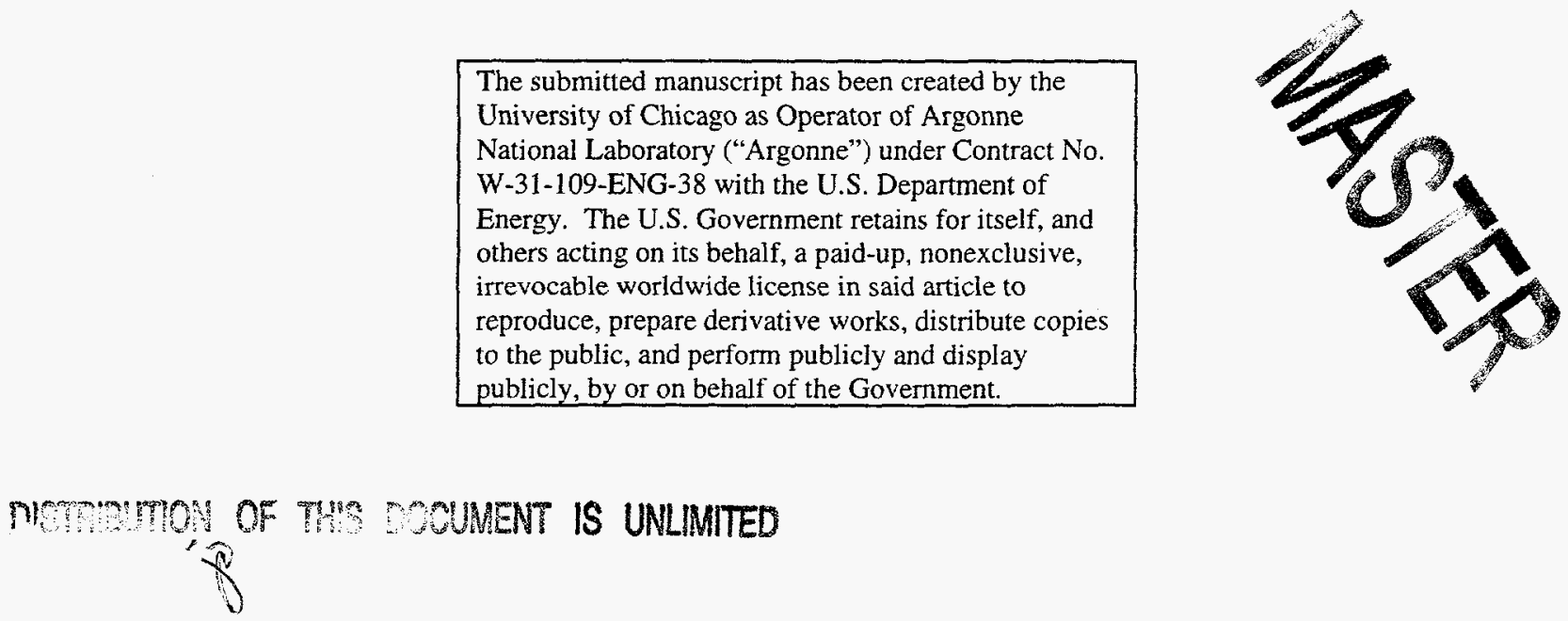

*Work at Argonne National Laboratory was sponsored by the U.S. Department of Energy (DOE), Energy Efficiency and Renewable Energy, as part of a DOE program to develop electric power technology, under Contract W-31-109-ENG-38. 


\section{DISCLAMER}

Portions of this document may be illegible in electronic image products. Images are produced from the best available original document. 


\title{
EFFECT OF LEAD CONTENT ON PHASE EVOLUTION AND MICROSTRUCTURAL DEVELOPMENT IN Ag-CLAD Bi-2223 COMPOSITE CONDUCTORS*
}

\author{
N.N. Merchant, V.A. Maroni, A.K. Fischer, S.E. Dorris, W. Zhong \\ and N. Ashcom \\ Argonne National Laboratory, \\ 9700 S. Cass Avenue, \\ Argonne, Illinois 60439
}

\begin{abstract}
A two powder process was used to prepare silver-sheathed monofilamentary $\mathrm{Bi} 1.8 \mathrm{~Pb}_{\mathrm{x}} \mathrm{Sr} 1.98 \mathrm{Ca} 1.97 \mathrm{Cu} 3.08 \mathrm{O} y$ (Bi-2223) tapes with varying lead contents, $x$, from 0.2 to 0.5 . The resulting tapes were subjected to thermomechanical processing and then characterized by $x$-ray diffraction (XRD), scanning electron microscopy (SEM), and energy dispersive $x$-ray analysis (EDX). Layered phase texture was accessed using image analysis software on scanned SEM micrographs. Transport currents were measured at $77 \mathrm{~K}$ and zero field by the four-probe method. It was found that tapes with low lead content $(x=0.2$ and 0.25$)$ showed incomplete conversion to $\mathrm{Bi}$ 2223 , had small grain size and poor c-axis texture. Tapes having higher lead content $(x=0.4$ and 0.5$)$ also showed incomplete conversion and the presence of lead-rich secondary phases. Tapes with lead content $x=0.3$ and 0.35 showed complete conversion to $\mathrm{Bi}-2223$, and had the least amount of secondary phases, the best c-axis texture, and the highest transport currents $U_{c}$ ). The carbon content of the precursor powder also had a strong influence on secondary-phase chemistry.
\end{abstract}

\section{DISCLAIMER}

\begin{abstract}
This report was prepared as an account of work sponsored by an agency of the United States Government. Neither the United States Gnvernment nor any agency thereof, nor any of their employees, makes any warranty, express or implied, or assumes any legal liability or responsibility for the accuracy, completeness, or usefulness of any information, apparatus, product, or process disclosed, or represents that its use would not infringe privately owned rights. Reference herein to any specific commercial product, process, or service by trade name, trademark, manufacturer, or otherwise does not necessarily constitute or imply its endorsement, recommendation, or favoring by the United States Government or any agency thereof. The views and opinions of authors expressed herein do not necessarily state or reflect those of the United States Government or any agency thereof.
\end{abstract}

* Work at Argonne National Laboratory was sponsored by the U.S. Department of Energy (DOE), Energy Efficiency and Renewable Energy, as part of a DOE program to develop electric power technology, under Contract W-31-109-ENG-38. 


\section{Introduction}

Since the discovery of the $110 \mathrm{~K}$ superconducting phase $\mathrm{Bi}_{2} \mathrm{Sr}_{2} \mathrm{Ca}_{2} \mathrm{Cu}_{3} \mathrm{O}_{y}(\mathrm{Bi}-2223)$ in 1988 [1,2], a great deal of research has been focused on optimization of its phase purity and microstructure [3-6]. Lead addition to the $\mathrm{Bi}-\mathrm{Sr}-\mathrm{Ca}-\mathrm{Cu}-\mathrm{O}$ system was shown to stabilize the $\mathrm{Bi}-2223$ phase and also accelerate the phase formation kinetics [7-9]. Other related studies revealed that the lead content is a critical variable in fabricating tapes by the two-powder process $[10,11]$.

Earlier studies by Dorris et al. [11-13] revealed that the optimum lead content in $\mathrm{Bi} 1.8 \mathrm{~Pb}_{\mathrm{x}} \mathrm{Sr}_{2} \mathrm{Ca}_{2} \mathrm{Cu}_{3} \mathrm{O}_{\mathrm{y}}$ is near $\mathrm{x}=0.4$ and that the mode of lead addition (whether in $\mathrm{Bi}_{2} \mathrm{Sr}_{2} \mathrm{CaCu}_{2} \mathrm{O}_{8}$ (Bi-2212) or in the secondary phases) is an important factor. However, no systematic work has been done to study the effect of lead content on the microstructure and superconducting properties of Ag-clad Bi-2223 composite conductors.

In this paper, we extend the prior work of Dorris et al. [11-13] to an investigation of microstructural evolution in two-powder $\mathrm{Ag} / \mathrm{Bi}-2223$ composite conductors containing $\mathrm{Bi}_{1} \mathrm{~Pb}_{\times} \mathrm{Pr}_{2} \mathrm{CaCu}_{2} \mathrm{O}_{8}$ with various lead contents in the range from $x=0.2$ to 0.5 .

\section{Experimental Procedure}

Lead-doped $\mathrm{Bi}_{1.8} \mathrm{~Pb}_{2} \mathrm{Sr}_{2} \mathrm{Ca}_{1.0} \mathrm{Cu}_{2} \mathrm{O}_{8}(\mathrm{Bi}-2212)$ powders were prepared with $\mathrm{x}$ values of $0.2,0.25,0.3,0.35,0.4$, and 0.5 . The six powder mixtures with appropriate amounts of $\mathrm{Bi}_{2} \mathrm{O}_{3}, \mathrm{PbO}, \mathrm{SrCO}_{3}, \mathrm{CaCO}_{3}$, and $\mathrm{CuO}$ were calcined first at a reduced total pressure of -3 torr $\mathrm{O}_{2}\left(20^{\circ} \mathrm{C} / \mathrm{h}\right.$ to $750^{\circ} \mathrm{C}$, followed by $6 \mathrm{~h}$ at $\left.750^{\circ} \mathrm{C}\right)$ to ensure complete decomposition of the carbonates. After calcining at reduced pressure, the $\mathrm{Bi}-2212$ phase was formed by further calcining for $24 \mathrm{~h}$ at $840^{\circ} \mathrm{C}$ in $\mathrm{CO}_{2}$-free air at ambient pressure. The powders were then ball milled in isopropyl alcohol for 12$16 \mathrm{~h}$ and calcined again for $24 \mathrm{~h}$ at $840^{\circ} \mathrm{C}$ in $\mathrm{CO}_{2}$-free air at ambient pressure. This sequence of calcinations in air followed by intermediate ball milling was repeated until near-single-phase materials were obtained. The powders were then calcined in argon to remove any $\mathrm{Ca}_{2} \mathrm{PbO}_{4}$ that may have formed and to ensure that all the lead was incorporated in the $\mathrm{Bi}-2212$ phase [14]. The Bi-2223 precursors were prepared by mixing each of the six lead-doped $\mathrm{Bi}-2212$ batches with an equimolar amount of $\mathrm{CaCuO}_{2}$, then ball milling in isopropyl alcohol for $12-16 \mathrm{~h}$ and calcining at -3 torr $\left(60^{\circ} \mathrm{C} / \mathrm{h}\right.$ to $720^{\circ} \mathrm{C}$, followed by $3 \mathrm{~h}$ at $720^{\circ} \mathrm{C}$ ) to eliminate carbon introduced during milling. Two separate batches of powder with lead content $x=0.4$ and 0.5 were not given this low temperature anneal (LTA) in order to study the effect of high residual carbon. Powder-in-tube (PIT) tapes were prepared from the $\mathrm{Bi}-2223$ precursor powders by a thermomechanical procedure described elsewhere [15].

Short samples $(\sim 3 \mathrm{~cm}$ long) were cut from the as-rolled tapes and heat treated in $8 \% \mathrm{O}_{2}$ at $820^{\circ} \mathrm{C}$. The samples were annealed for $50 \mathrm{~h}$, then uniaxially cold pressed at $\sim 2 \mathrm{GPa}$. Following pressing, the tapes were annealed for an additional $100 \mathrm{~h}$ at $820^{\circ} \mathrm{C}$. The process of annealing and pressing was repeated until cumulative heattreatment times of $250 \mathrm{~h}$ had been reached. The fully-processed samples typically were 100 to $120 \mu \mathrm{m}$ thick. Ramp rates from ambient temperature to processing 
temperature and cool down to ambient temperature were $60^{\circ} \mathrm{C} / \mathrm{h}$. The $\mathrm{J}_{\mathrm{C}}$ of each tape was measured at $77 \mathrm{~K}$ and zero field by the four-probe method, using the 1 $\mu \mathrm{V} / \mathrm{cm}$ criterion. X-ray diffraction (XRD) was performed on peeled sections of fully processed tape samples using a Philips Diffractometer. The conversion of Bi-2212 to $\mathrm{Bi}-2223$ was computed on the basis of $\mathrm{x}$-ray intensity ratios of the $(0010)_{2223}$ and (008) 2212 diffraction lines. Scanning electron microscopy (SEM) and energy dispersive $x$-ray (EDX) analysis were done with a JEOL 6400 SEM unit coupled to a Noran EDX unit. Texture analysis was carried out on scanned SEM images using Agfa Arcus II scanner along with Adobe Photoshop and NIH Image software [16].

\section{Results and Discussion}

\section{Compositions and Conversion Kinetics}

Table I shows the compositions of the six precursor powders as determined by inductively coupled plasma/atomic emission spectroscopy (ICP/AES). The lead content in all the powders is very close to the desired stoichiometry. Copper exhibits the greatest deviation from the desired value but the maximum deviation is less than 3 percent. Figure 1 shows a bar plot of percent conversion to Bi-2223 versus lead content, $x$, for the eight tapes used in this study. These tapes were processed for $250 \mathrm{~h}$ in $8 \% \mathrm{O}_{2}$ at $820^{\circ} \mathrm{C}$. From the plot it is clear that the LTA tapes with lead contents in the range 0.3 to 0.4 are nearly $100 \%$ Bi-2223. Tapes with lower lead content $(0.2$ and 0.25$)$ show incomplete conversion to Bi-2223, presumably due to inadequate liquid phase formation because of lead deficiency. Compositions that have the highest lead content (0.5) or high carbon contents (no LTA), also show incomplete conversion. This may be due to accelerated secondary phase growth in these samples during the early stages of conversion.

\section{Microstructure and Texture Studies}

Figure 2 presents SEM micrographs of longitudinal sections (after etching) of the LTA tapes with lead contents $x=0.2,0.3,0.4$ and 0.5 . It can be seen from the micrographs that the sample with $x=0.2$ has very poor texture, small grains and no platy structure. This is consistent with the fact that the $x=0.2$ tape is expected to have the least amount of liquid phase formed due to lead deficiency. In the microstructure for $\mathrm{x}=0.3$, the $\mathrm{Bi}-2223$ layered phase has large grains with good texture. The microstructures with $\mathrm{x}=0.4$ and 0.5 , has disrupted grains with a platy

Table I. Stoichiometric compositions of Bi-2223 precursor powders determined by ICP-AES.

\begin{tabular}{|cccccc|}
\hline Sample No. & $\mathrm{Bi}$ & $\mathrm{Pb}$ & $\mathrm{Sr}$ & $\mathrm{Ca}$ & $\mathrm{Cu}$ \\
\hline 1 & 1.82 & 0.20 & 1.98 & 1.95 & 3.05 \\
2 & 1.81 & 0.25 & 1.97 & 1.97 & 3.06 \\
3 & 1.80 & 0.29 & 1.96 & 1.98 & 3.07 \\
4 & 1.80 & 0.35 & 1.98 & 1.98 & 3.07 \\
5 & 1.77 & 0.39 & 1.98 & 1.97 & 3.09 \\
6 & 1.79 & 0.49 & 1.97 & 1.96 & 3.09 \\
\hline
\end{tabular}




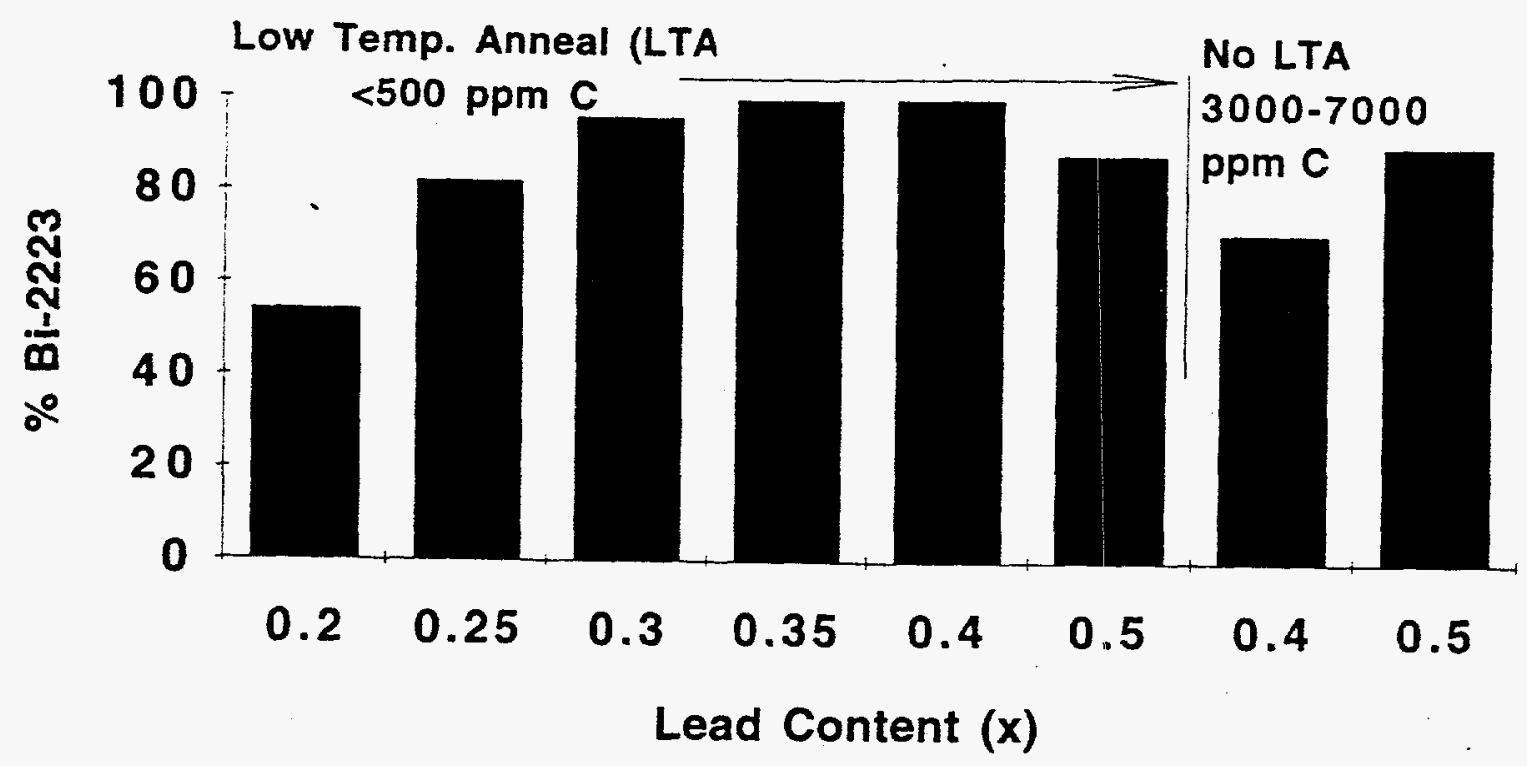

Figure 1. Effect of lead content and low temperature anneal on conversion kinetics in Ag-clad Bi-2223 composite conductors.

appearance.

Figure 3 depicts the average grain orientation (with respect to the silver interface) in various tapes versus lead content. The average grain orientation was obtained by using image analysis software on scanned SEM micrographs of longitudinal sections of samples, such as those in Figure 2. It can be seen that layered phase grains in the composite with $x=0.3$ have the lowest average angle with respect to the silver interface. This tape thus exhibits the best Bi-2223 grain texture. The orientation of the layered phase grain improves from $x=0.2$ to $x=0.3$ but does not change significantly for the LTA samples with $x>0.3$. The samples with $x=0.4$ and $x=0.5$ that did not receive the LTA show poorer texture than their counterparts that did receive the LTA.

Figure 4 shows SEM micrographs taken in the backscatter mode on transverse sections of the fully processed tapes with the higher lead contents $(0.4$ and 0.5$)$ that were not subjected to LTA and, consequently, had carbon contents in the 3000 to $7000 \mathrm{ppm}$ range. It can be seen that the sample with $x=0.4$ contains large secondary phases, mostly of the $(\mathrm{Ca}, \mathrm{Sr}) 14 \mathrm{Cu} 24 \mathrm{O} 41$ type. The sample with $\mathrm{x}=0.5$ shows a large number of Sr-rich phases (black) apart from the white streaky phases that are the lead-rich phases (3221 and plumbates). It is our belief that the Sr-rich regions are created during heat treatment of the high-carbon composites, initially as $\mathrm{SrCO}_{3}$ that eventually decomposes to $\mathrm{SrO}$ agglomerates, which persist throughout the processing but eventually become carbonates again when the core is exposed to air during specimen mounting. The presence of $(\mathrm{Bi} / \mathrm{Pb})$-rich and $\mathrm{Sr}-$ 

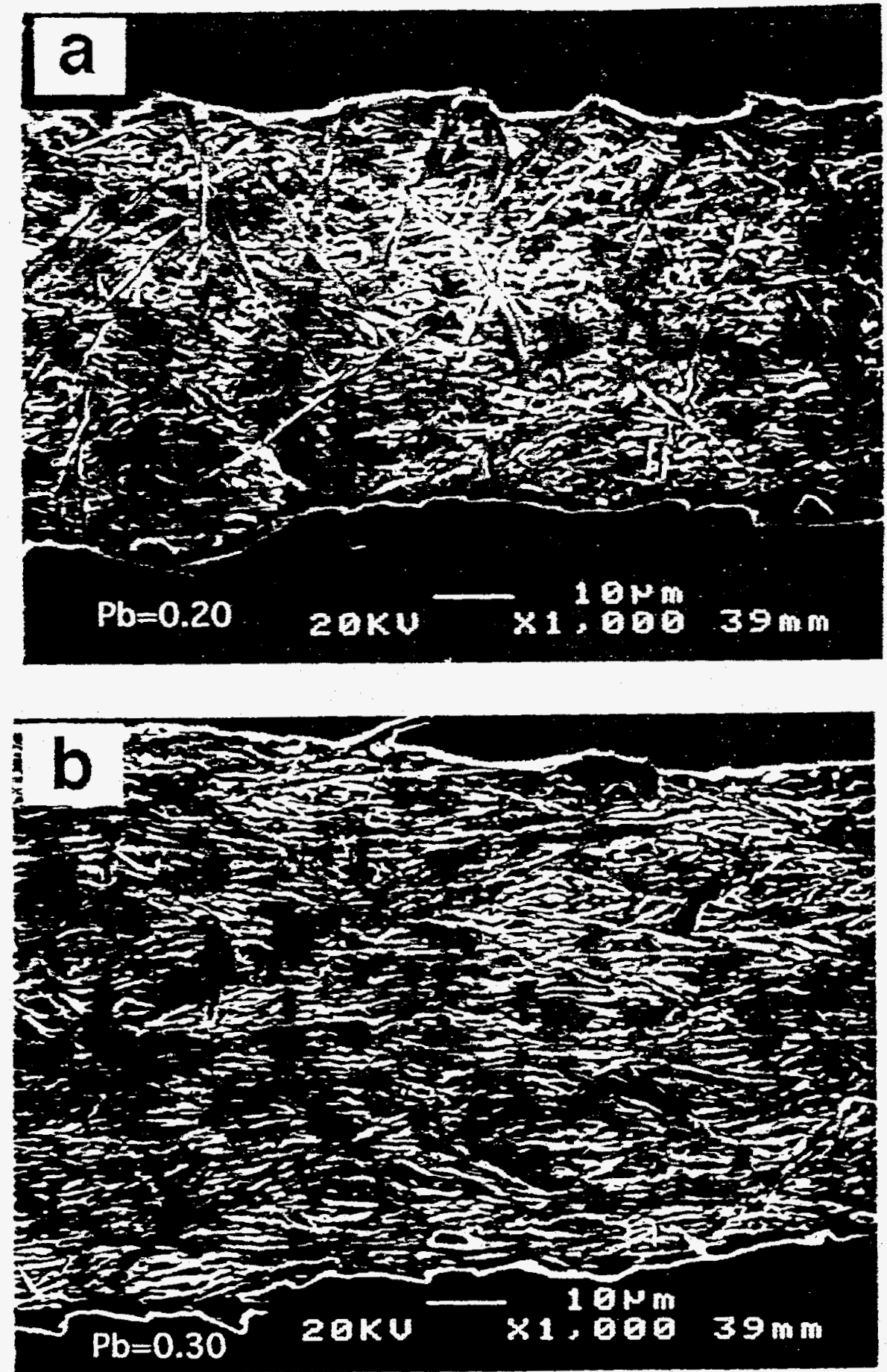

Figure 2. SEM images of longitudinal sections of fuly processed tapes after etching: the lead contents were (a) $P b=0.2$, (b) $P b=0.3,(c) P b=0.1$, and (d) $P b=0.5$. (The powder in each of these tapes revind the low temperature anneal.) 

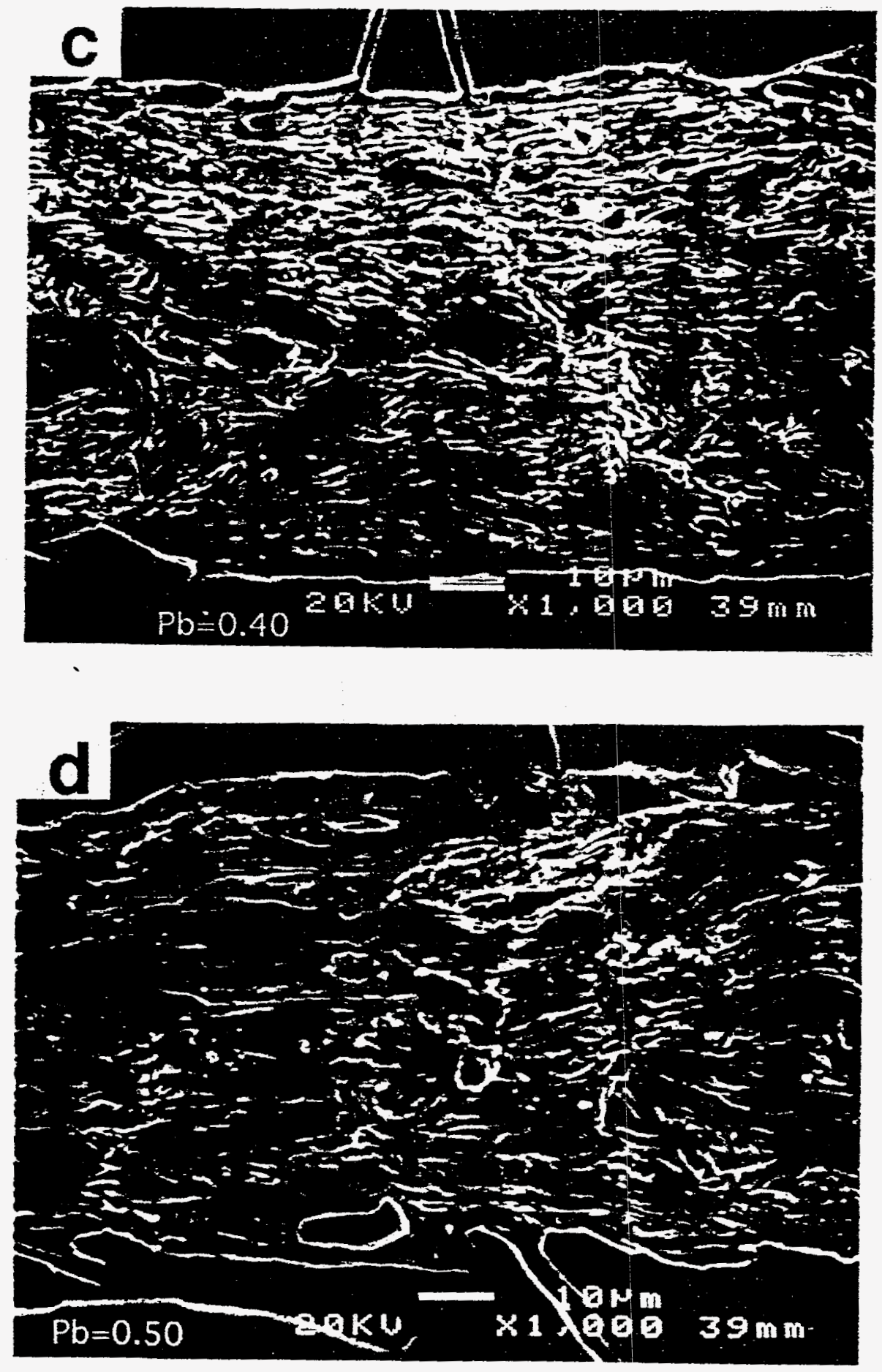

Figure 2 (Continued) 
rich phases has been independently confirmed by Luo et al. [17] using Raman microspectroscopy. SEM studies on samples with lead content 0.2 and 0.25 revealed presence of many secondary phases that were mostly $(\mathrm{Ca}, \mathrm{Sr})_{2} \mathrm{CuO}_{3}$ and $(\mathrm{Ca}, \mathrm{Sr})_{14} \mathrm{Cu}_{24} \mathrm{O}_{41}$ type. The extent of conversion to $\mathrm{Bi}-2223$ in these samples was only $60-80 \%$. The appearance of $\mathrm{Bi} / \mathrm{Pb}$-rich phases for $\mathrm{x}>0.3$ and the increase in their concentration with $\mathrm{Pb}$ content indicate that the solubility limit for lead in $\mathrm{Bi}$ 2223 lies between $x=0.2$ and $x=0.5$. This limit probably is in the vicinity of $x=0.3$, judging from the minimal secondary phase content in samples with this lead content.

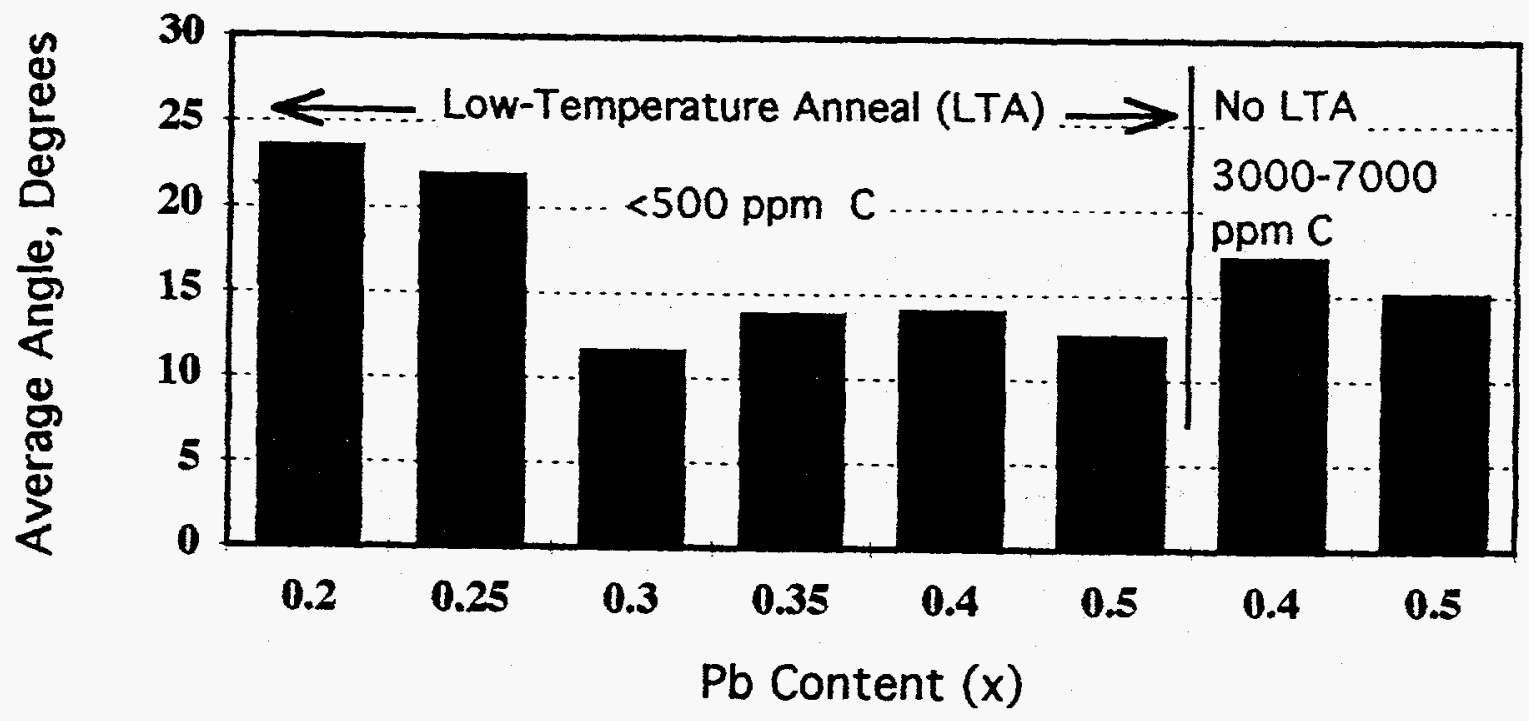

Figure 3. Plot of average layered-phase grain orientation with respect to the silver interface versus lead content.

\section{Superconducting Properties}

Figure 5 presents a plot of critical current $\left(\mathrm{I}_{\mathrm{C}}\right)$ versus lead content for the fully processed tapes after 50,100 , and $250 \mathrm{~h}$ of anneal in $8 \% \mathrm{O}_{2}$ at $820^{\circ} \mathrm{C}$. The $\mathrm{I}_{\mathrm{C}}$ data are in good agreement with the SEM studies and the texture analysis. The $I_{C}$ increases 

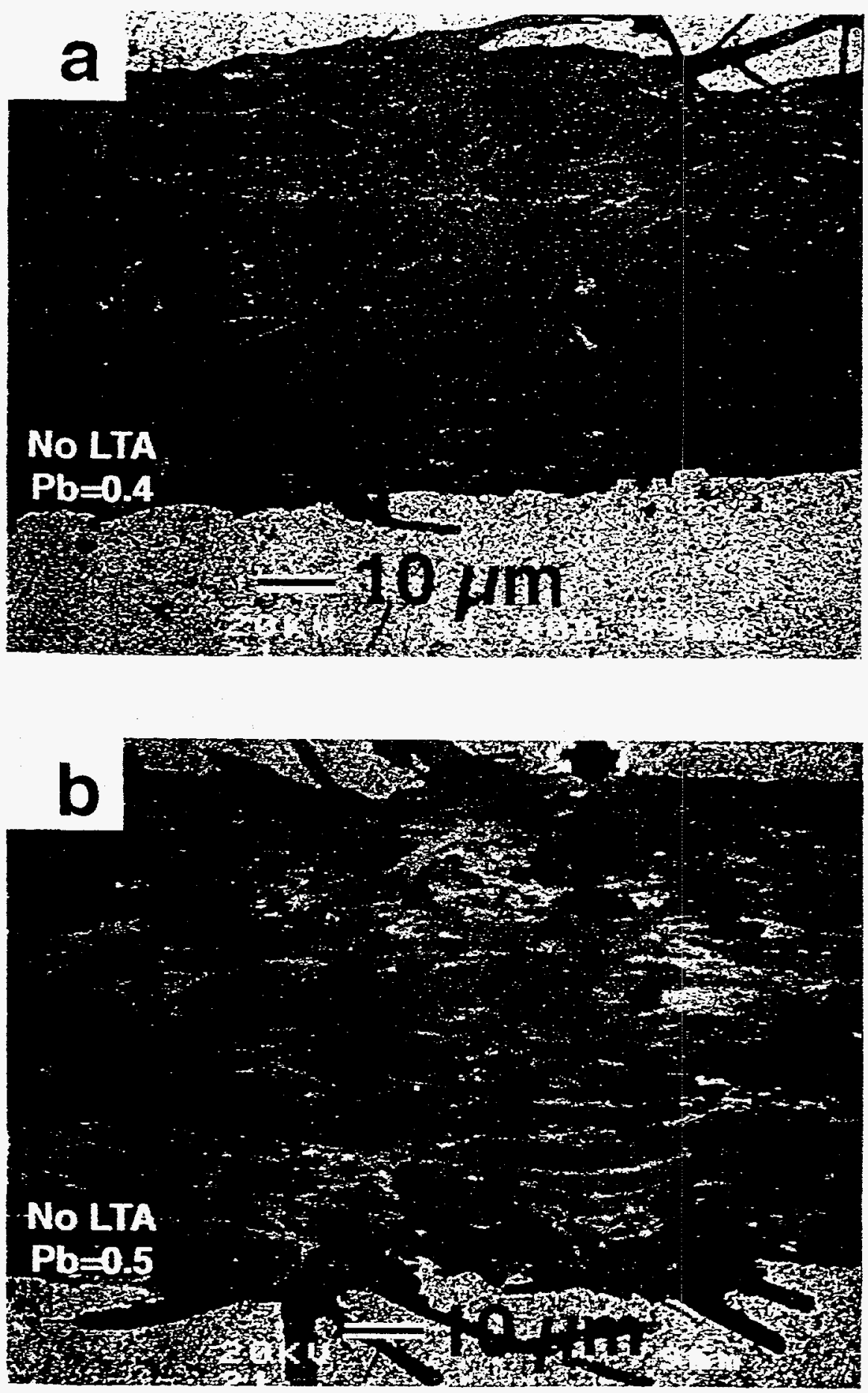

Figure 4. SEM images (in backscatter mude) of transicue sectins at tapes with (a)

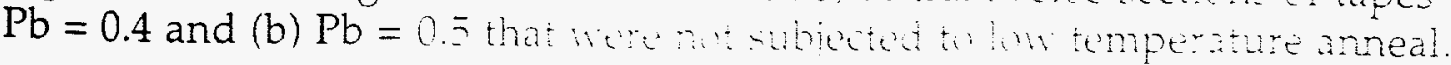


significantly from $x=0.2$ to $x=0.3$ and then drops down with further lead increase from 0.3 to 0.5 . The $I_{C}$ values of the two tapes prepared with powders that did not receive the LTA were significantly lower than those that had the LTA. This is again consistent with microstructural studies of the same sample. The lead-rich phases tend to coat the superconducting grain boundaries and presumably have a deleterious effect on the current flow.

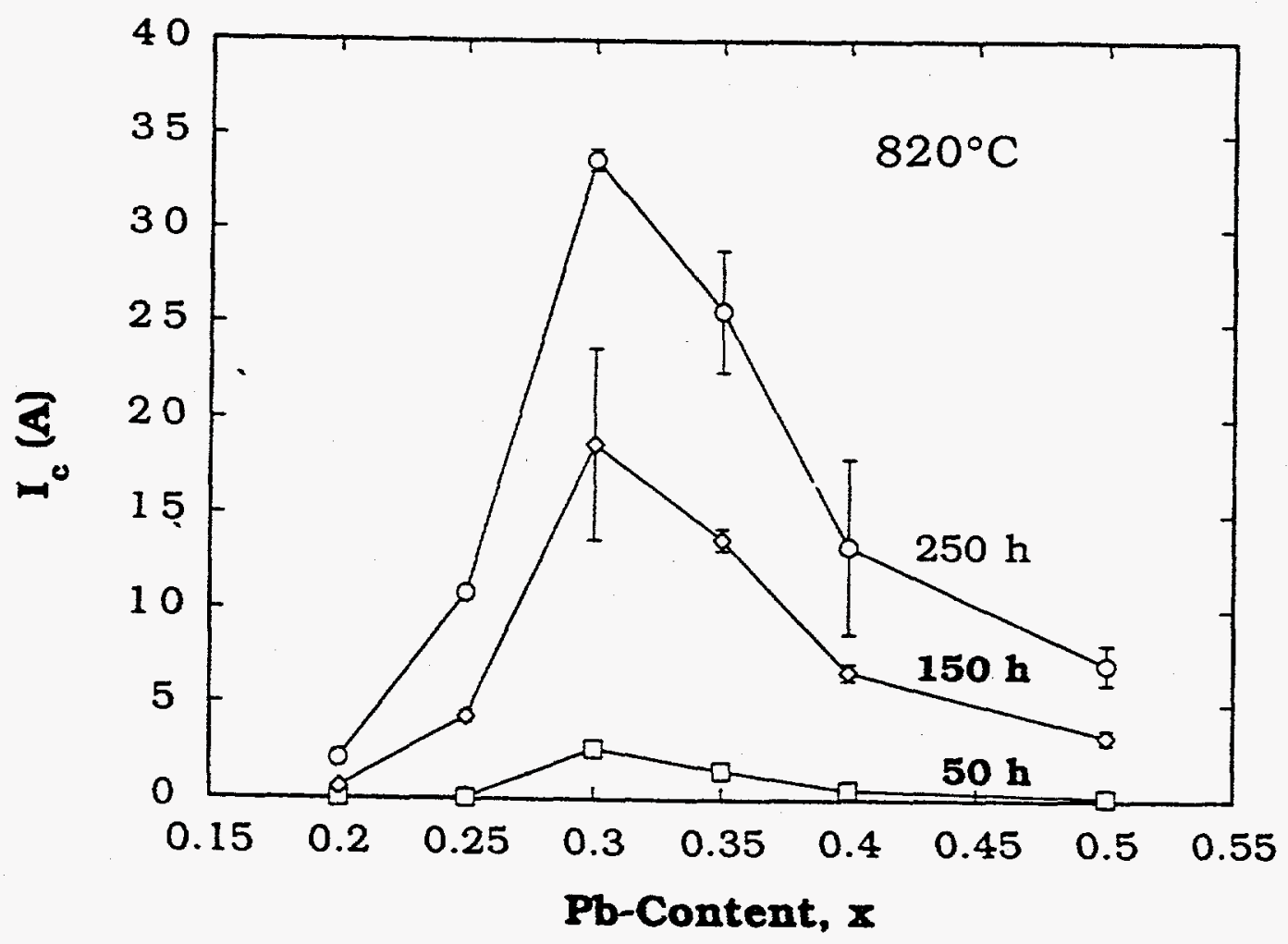

Figure 5. Plot of critical current $I_{C}$ at $77 \mathrm{~K}$ and zero field versus lead content.

\section{Conclusion}

In summation, we find that as the lead content $\mathrm{x}$ in $\mathrm{Bi} 1.8 \mathrm{~Pb}_{\mathrm{x}} \mathrm{Sr}_{2.0 \mathrm{Ca}} .0 \mathrm{Cu} 3.1 \mathrm{O}_{\mathrm{y}}$ increases from 0.2 to 0.3 , (1) layered-phase grain size increases, (2) layered-phase texture improves, and (3) transport $I_{C}$ increases. As the lead content $x$ is further increased from 0.3 to 0.5 , (1) secondary-phase particle size and quantity increase, (2) platy-growth frequency and depth increase, (3) the amount of detectable lead-rich phase increases, and (4) transport $\mathrm{I}_{\mathrm{C}}$ decreases. Reducing the carbon content from $>3000 \mathrm{ppm}$ to $<500 \mathrm{ppm}$ (e.g., by use of the low temperature anneal ) (1) reduces the occurrence of Sr-rich phases, (2) reduces the size and quantity of secondary phases, and (3) leads to measurable improvement in texturing and $I_{C}$. 


\section{$\underline{\text { References }}$}

1. H Maeda, Y. Tanaka, M. Fukutomi, and T. Asano, Ipn. I. Appl. Phys. 27 (1988), L209.

2.J.M. Tarascon, Y. LePage, L.H. Greene, B.G. Bagley, P. Barboux, D.W. Hwang, G.W. Hull, W.R. McKinnon, and M. Giroud, Phys. Rev. B 38 (1988), 2504.

3. G.N. Riley Jr. and W.L. Carter, Am. Ceram. Soc. Bull., 72 (1993), 91; U. Balachandran, A.N. Iyer, P. Haldar, and L.R. Motowidlo, I. Met. 45 (1993), 54; E.E. Hellstrom, MRS Bulletin, 17 (1992), 45.

4. S.X. Dou and H.K. Liu, Materials Science Forum 137-139 (1993), 649.

5. Y.S. Sung and E.E. Hellstrom, I. Am. Ceram. Soc. Bull., 78 (1995), 2003.

6. C.L. Briant, E.L. Hall, K.W. Lay, and J.E. Tkaczyk, L. Mater. Res. 9 (1994), 2789.

7. S. M. Green, C. Jiang, M. Yu, H.L. Luo, and C. Politis, Phys. Rev. B, 38 (1988), 5016.

8. D. Shi, M.S. Boley, J.G. Chen, M. Xu, K. Vandervoort, Y.X. Liao, and A. Zangvil, Appl. Phys. Lett., 55 (1989), 699.

9. M. Mizuna, H. Endo, J. Tsuchiya, N. Kijiima, A.S. Dumiyama, and Y. Oguri, Ipn. I. Appl. Phys., 27 (1988), L1225.

10. S.E. Dorris, M.A. Pitz, J.T. Dawley, and D.J. Trapp, L. Elect. Mater. 24 (1995) 1835.

11. J.S. Luo, S.E. Dorris, A.K. Fischer, J.S. LeBoy, V.A. Maroni, Y. Feng, and D.C. Larbalestier, Supercond. Sci. Technol., 9 (1996), 412.

12. S.E. Dorris, B.C. Prorok, M.T. Lanagan, S. Sinha, and R.B. Poeppel, Physica C, 211 (1993), 66.

13. S.E. Dorris, B.C. Prorok, M.T. Lanagan, N.B. Browning, M.R. Hagen, J.A. Parrell, Y. Feng, A. Umezawa, and D.C. Larbalestier, Physica C, 223 (1994), 163.

14. A. Jeremie, K. Alami-Yadri, J.C. Grivel, and R. Flukiger, Supercond. Sci. Tech. 6 (1993), 730.

15. S.E. Dorris, B.C. Prorok, M.T. Lanagan, S. Sinha, and R.B. Poeppel, Physica C 212 (1993) 66.

16. J.S. Luo, N. Merchant, E. Escorcia-Aparicio, V.A. Maroni, D.M. Gruen, B.S. Tani, G.N. Riley Jr., and W.L. Carter, I. Mater. Res., 9 (1994), 3059.

17. J.S. Luo, N. Merchant, V.A. Maroni, M.Hash, and M. Rupich, Proceedings of 1996 TMS Annual Meeting, in Anaheim, California, Feb. 4-8, 1996, p. 33. 